\title{
Copper leaching from waste electric cables by biohydrometallurgy
}

\author{
Fanny Lambert ${ }^{\mathrm{a}, *}$, Stoyan Gaydardzhiev ${ }^{\mathrm{a}}$, Grégoire Léonard ${ }^{\mathrm{b}}$, Gregory Lewis ${ }^{\mathrm{c}}$, Pierre-François Bareel ${ }^{\mathrm{c}}$, \\ David Bastin $^{\text {a }}$
}

${ }^{a}$ Laboratory of Mineral Processing and Recycling, University of Liege, Chemin des chevreuils B52, Liege, Belgium

${ }^{\mathrm{b}}$ Laboratory of Chemical Engineering, University of Liege, Allee de la Chimie B6a, Liege, Belgium

${ }^{\mathrm{c}}$ Comet Traitements SA, Rivage du Boubier, Châtelet, Belgium

\section{A R T I C L E I N F O}

\section{Article history:}

Received 17 July 2014

Revised 17 December 2014

Accepted 18 December 2014

Available online $\mathrm{xxxx}$

\section{Keywords:}

Recycling

Cables

Leaching

Bioleaching

Acidithiobacillus ferrooxidans

\begin{abstract}
A B S T R A C T
This study examines the leaching of copper from waste electric cables by chemical leaching and leaching catalysed by Acidithiobacillus ferrooxidans in terms of leaching kinetics and reagents consumption. Operational parameters such as the nature of the oxidant $\left(\mathrm{Fe}^{3+}, \mathrm{O}_{2}\right)$, the initial ferric iron concentration $(0-10 \mathrm{~g} / \mathrm{L})$ and the temperature $\left(21-50^{\circ} \mathrm{C}\right)$ were identified to have an important influence on the degree of copper solubilisation. At optimal process conditions, copper extraction above $90 \%$ was achieved in both leaching systems, with a leaching duration of 1 day. The bacterial leaching system slightly outperformed the chemical one but the positive effect of regeneration of $\mathrm{Fe}^{3+}$ was limited. It appears that the $\mathrm{Fe}^{2+}$ bio-oxidation is not sufficiently optimised. Best results in terms of copper solubilisation kinetics were obtained for the abiotic test at $50{ }^{\circ} \mathrm{C}$ and for the biotic test at $35^{\circ} \mathrm{C}$. Moreover, the study showed that in same operating conditions, a lower acid consumption was recorded for the biotic test than for the abiotic test.
\end{abstract}

(ㄷ) 2014 Elsevier Ltd. All rights reserved.

\section{Introduction}

Electric cables are components widely used in sectors like transport, construction, communication and consumer goods. They are constituents of items such as automobiles and electrical and electronic equipment.

During the recycling of WEEE and ELV, electric cables are isolated by hand picking or other physical separations. The obtained cables concentrate is traditionally sorted through physical separation methods such as shredding, screening, as well as gravity and electrostatic separations. These physical separations lead to important copper losses, around $32 \%$ in weight of the processed electric cables. The residues coming from these processes are usually dumped even though they are a non-negligible secondary source of metals. This study focuses on the residue coming from the recycling of electric cables of ELV and WEEE. It contains copper and aluminium but also a mixture of plastics (PVC, PER, EFTE, PET, PU).

End-of-life vehicles (ELV) and waste electrical and electronic equipment (WEEE) are facing more stringent legislative pressures concerning the recycling rate: different targets must be reached by 2015 and by 2018 in Europe (Directive 2000/53/CE and Directive 2012/19/UE). To achieve these targets, some not-yet treated

\footnotetext{
* Corresponding author.

E-mail address: Fanny.Lambert@ulg.ac.be (F. Lambert).
}

waste flows must be considered as residues coming from recycling of electric cables. New technologies have to be sought. In this context, hydrometallurgy could be suggested as an alternative way to recover the copper from low-grade residues.

Bioleaching technology was only investigated recently to process polymetallic wastes such as printed circuit boards (PCB) (Wang and et al., 2009; Yang et al., 2009; Liang et al., 2010; Xiang et al., 2010), electronic scraps (Brandl et al., 2001; Ilyas et al., 2007) shredder residues (Lewis et al., 2011). For this purpose, chemolithotrophic bacteria from the specie Acidithiobacillus ferrooxidans were mostly studied as a mean to regenerate ferric from ferrous iron. High metal recoveries were reported for bioleaching of $\mathrm{Cu}$ from electronic scrap (Brandl et al., 2001) and PCB (Wang et al., 2009; Yang et al., 2009). In previous projects we have investigated the feasibility of bacterially assisted leaching to bring zero-valent copper in solution from similar material. Favourable metal solubilisation rates were achieved (Lewis et al., 2011; Gaydardzhiev, 2010).

The existing studies examine the feasibility of biohydrometallurgy although they do not systematically distinguish the part coming from the chemistry and the real benefit of bacteria presence. This paper focuses on the comparison of the chemical leaching and the indirect bacterial leaching in terms of leaching time and copper extraction. The objective is to evaluate the technical efficiency of both hydrometallurgical routes. Therefore at this 
initial stage, selected process parameters such as ferric iron concentration, total iron concentration and temperature were studied.

\section{Materials and methods}

\subsection{Material}

The sample is composed of electric cables coming from end-oflife vehicles. Electric cables were crushed by a knife mill and were processed by a two-step gravity separation (upstream air classifier and vibrating pneumatic table). This separation leads to the recovery of a high grade copper concentrate but a part of the copper is lost in a low density fraction. This fraction is the sample subject of the current investigation.

For quantitative determination of metals, cables were initially ignited at $850{ }^{\circ} \mathrm{C}$ for $30 \mathrm{~min}$ to remove organic fractions (loss on ignition). Further on, the remaining ashes were digested subsequently in nitric acid and aqua regia. The obtained aliquots were analysed by Inductively Coupled Plasma Optical Emission Spectrometry (ICP-OES). Plastics were analysed by infrared.

The sample consists mainly of various plastic fragments and copper wires. Chemical analysis indicates that the sample contains $4.9 \%$ copper and $0.6 \%$ aluminium. The plastics are mainly PVC and PER, but also EFTE, PET and PU. The size of particles is below $5 \mathrm{~mm}$. Copper and aluminium wires are well liberated from the plastics.

\subsection{Microorganisms and culture conditions}

The mixed bacterial culture comes from the University of Mining and Geology of Sofia (Bulgaria). The culture initially contained A. ferrooxidans, Leptospirilum ferrooxidans and Acidithiobacillus thiooxidans but $A$. ferrooxidans is the prevalent microbial specie. To avoid the inhibition of the bacterial activity in presence of metallic cations (mainly $\mathrm{Cu}^{2+}$ and $\mathrm{Al}^{3+}$ ), the bacterial consortium was adapted to copper and aluminium concentrations higher than the concentrations of the pregnant leach solution. The nutrient medium used to maintain bacterial growth was the Lundgren-Silverman $9 \mathrm{~K}$ liquor which has the following composition: $\left(\mathrm{NH}_{4}\right)_{2} \mathrm{SO}_{4} 3.0 \mathrm{~g} / \mathrm{L}, \mathrm{KCl} 0.1 \mathrm{~g} / \mathrm{L}, \mathrm{K}_{2} \mathrm{HPO}_{4} 0.5 \mathrm{~g} / \mathrm{L}, \mathrm{MgSO}_{4-}$ $.7 \mathrm{H}_{2} \mathrm{O} \quad 0.5 \mathrm{~g} / \mathrm{L}, \mathrm{Ca}\left(\mathrm{NO}_{3}\right)_{2} \quad 0.01 \mathrm{~g} / \mathrm{L}, \quad \mathrm{FeSO}_{4} \cdot 7 \mathrm{H}_{2} \mathrm{O} \quad 44.2 \mathrm{~g} / \mathrm{L}$ (Rossi, 1990). Bacteria were cultured in a fermenter fed in semi-continuous by the nutrient medium with $16 \mathrm{~g} / \mathrm{L} \mathrm{Cu}^{2+}$ and $1 \mathrm{~g} / \mathrm{L} \mathrm{Al}^{3+}$. The quantitative determination of microorganisms during experiments was carried out by a serial end-point dilution technique, commonly referred to as "Most Probable Number" method (Karavaiko et al., 1988).

\subsection{Leaching procedure}

Fourteen tests were considered to cover the influence of the selected operating parameters. The operational conditions are presented in Table 1 . The tests are classified in abiotic and biotic tests; thymol was added as bactericide for all abiotic tests to avoid a bacterial growth. Temperature $\left(21,35,50{ }^{\circ} \mathrm{C}\right)$, ferric iron concentration $(0,1,2,6$ and $7 \mathrm{~g} / \mathrm{L})$ and total iron concentration $(0-10 \mathrm{~g} / \mathrm{L})$ were investigated. The initial ferric iron concentration of the biotic tests is determined by the ratio between the inoculum coming from the fermenter $\left(6-7 \mathrm{~g} / \mathrm{L} \mathrm{Fe}^{3+}\right)$ and the Lundgren-Silverman $9 \mathrm{~K}$ medium: $10-90 \%$ for the tests $7,8,9,10,12,14$ (resulting in $0.5-2 \mathrm{~g} / \mathrm{L}$ initial $\mathrm{Fe}^{3+}$ ) and $100-0 \%$ for the test 11 (resulting in $7 \mathrm{~g} / \mathrm{L}$ initial $\mathrm{Fe}^{3+}$ ). Some abiotic (tests 3, 4 and 13) were prepared as the first biotic tests, i.e. by mixing $10 \%$ inoculum and $90 \% 9 \mathrm{k}$ medium (resulting in $0.5-2 \mathrm{~g} / \mathrm{L}$ initial $\mathrm{Fe}^{3+}$ ), and thymol was added as bactericidal agent. On the contrary, the abiotic tests 1,5 and 6 were prepared with ferric iron sulphate $\mathrm{Fe}_{2}\left(\mathrm{SO}_{4}\right)_{3} \cdot 7 \mathrm{H}_{2} \mathrm{O}\left(6-7 \mathrm{~g} / \mathrm{L}\right.$ initial $\left.\mathrm{Fe}^{3+}\right)$ as ferric iron source. One blank was carried out with $0 \mathrm{~g} / \mathrm{L} \mathrm{Fe}^{3+}$ (test 2 ). The initial measured redox potential is directly related to the initial ratio $\left[\mathrm{Fe}^{3+}\right] /\left[\mathrm{Fe}^{2+}\right]$ as described by the Nernst equation. The tests $4,10,13$ and 14 were carried out with an air injection in the reactor with a flow rate fixed at $3 \mathrm{~mL} / \mathrm{min}$, in order to improve the $\mathrm{Fe}^{2+}$ bio-oxidation and the copper dissolution. Other tests were carried out without air injection but aeration takes place through mechanical agitation. Averages of dissolved oxygen concentrations during the experiments are directly associated with the air injection. The last two experiments (tests 13 and 14) were performed with a synthetic sample to simplify and better understand the chemical system. These tests were made up with the same metallic content as for other tests ( $4.9 \%$ and $0.6 \%$ of analytical copper and aluminium respectively) but without plastics. In fact, plastics have an impact on the chemical system (acid consumption) and could also have an impact on the bacterial activity. Plastics were replaced by $\mathrm{SiO}_{2}$ to keep the same solid content as in other tests. The tests 13 and 14 represent a simplified chemical system with pure copper and aluminium and without potential contaminants like plastics and minors chemical elements.

Representative samples were obtained by a riffle separator. In all configurations, a pulp density of $9 \%$ was used, so tests were carried out with a mass sample of $45-55 \mathrm{~g}$ and a volume of solution of $450-550 \mathrm{~mL}$. Leaching experiments were carried out inside a 0.5 -liter double jacket reactor, mechanically stirred at $700 \mathrm{rpm}$. The reactor was linked to a thermostatic bath in order to keep the temperature constant. Redox (vs. SHE) and pH measurements were continuously recorded using a control unit. Because of the alkaline nature of the material, sulphuric acid injection was necessary to keep the $\mathrm{pH}$ constant. The automatic acid addition was implemented through a micropump connected with the control unit. The $\mathrm{pH}$ was fixed at 1.9 to ensure optimal conditions of bacterial growth and minimise iron precipitation. The leach solution was placed in the reactor and was put at temperature and at $\mathrm{pH}=1.9$ before the addition of the solid. Samples of pregnant leach solutions were taken on a daily basis to carry out analysis of $\mathrm{Cu}, \mathrm{Fe}^{2+}$, total $\mathrm{Fe}$ and sulphuric acid consumption. Water evaporation was offset by distilled water addition. At the end of each experiment (from 1 to 7 days), the pulp was filtered to separate the pregnant leach solution from the solid leach residue. Both were analysed.

\subsection{Analytical methods}

Metals in the pregnant leach solution were analysed by atomic absorption and ICP-OES. The solid residue after leaching were dried, burnt at $850{ }^{\circ} \mathrm{C}$ for $30 \mathrm{~min}$, grinded in an agate mortar and digested in nitric acid before being chemically analysed by atomic absorption and ICP-OES. Ferrous iron concentration was determined by $\mathrm{K}_{2} \mathrm{Cr}_{2} \mathrm{O}_{7}$ titration and ferric iron was calculated as a difference between total and ferrous iron.

\section{Results and discussion}

\subsection{Electrochemical mechanisms of the studied system}

The chemical system studied is composed by the non-exhaustive following chemical species: $\mathrm{Cu}^{0}-\mathrm{Cu}^{2+}, \mathrm{Fe}^{2+}-\mathrm{Fe}^{3+}, \mathrm{Al}^{0}-\mathrm{Al}^{3+}, \mathrm{O}_{2}$, $\mathrm{H}^{+}, \mathrm{SO}_{4}^{2-}$. The differences between the standard reduction potentials of demi-reaction $\left(\Delta E^{0}\right)$ predict the reactions that can take place from a thermodynamic perspective: 
Table 1

Operating conditions for the fourteen leaching experiments.

\begin{tabular}{|c|c|c|c|c|c|c|c|c|c|}
\hline Tests & Bio/abiotic & Temp. $\left({ }^{\circ} \mathrm{C}\right)$ & $\begin{array}{l}\text { Initial } \mathrm{Fe}^{3+} \\
(\mathrm{g} / \mathrm{L})\end{array}$ & $\begin{array}{l}\text { Initial total Fe } \\
(\mathrm{g} / \mathrm{L})\end{array}$ & Inoculum (\%) & Initial redox $(\mathrm{mV})$ & Air injection & $\begin{array}{l}\text { Dissolved oxygen } \\
(\mathrm{mg} / \mathrm{L})\end{array}$ & Presence of plastics \\
\hline 1 & Abiotic & 21 & 7.0 & 8.0 & 0 & 793 & No & N.M. ${ }^{b}$ & Yes \\
\hline 2 & Abiotic & 35 & 0.0 & 0.0 & 0 & 733 & No & 3.5 & Yes \\
\hline 3 & Abiotic & 35 & 0.6 & 9.2 & 10 & 576 & No & 4.5 & Yes \\
\hline 4 & Abiotic & 35 & 1.9 & 10.2 & 10 & 563 & Yes & 6.4 & Yes \\
\hline 5 & Abiotic & 35 & 6.4 & 7.8 & 0 & 725 & No & N.M. & Yes \\
\hline 6 & Abiotic & 50 & 6.4 & 6.8 & 0 & 834 & No & N.M. & Yes \\
\hline 7 & Biotic & 21 & 0.9 & 9.0 & 10 & 639 & No & 3.0 & Yes \\
\hline 8 & Biotic & 35 & 0.5 & 9.2 & 10 & 556 & No & 3.5 & Yes \\
\hline 9 & Biotic & 35 & 1.2 & 9.4 & 10 & 656 & No & 2.4 & Yes \\
\hline 10 & Biotic & 35 & 1.9 & 10.1 & 10 & 564 & Yes & 6.7 & Yes \\
\hline 11 & Biotic & 35 & 7.0 & 7.0 & 100 & 888 & No & 3.3 & Yes \\
\hline 12 & Biotic & 50 & 1.2 & 8.8 & 10 & 680 & No & 2.7 & Yes \\
\hline 13 & Abiotic & 35 & 0.7 & 10.5 & 10 & 580 & Yes & $>6$ & No \\
\hline 14 & Biotic & 35 & 1.2 & 10.5 & 10 & 573 & Yes & $>6$ & No \\
\hline
\end{tabular}

a Standard Hydrogen Electrode (SHE).

b Not measured.

$\mathrm{Al}^{0}+3 \mathrm{Fe}^{3+} \rightarrow \mathrm{Al}^{3+}+3 \mathrm{Fe}^{2+}$

$\Delta E^{0}=0.77-(-1.66)=2.43 \mathrm{~V}$

$3 \mathrm{Cu}^{2+}+2 \mathrm{Al}^{0} \rightarrow 3 \mathrm{Cu}^{0}+2 \mathrm{Al}^{3+}$

$\Delta E^{0}=0.34-(-1.66)=2.00 \mathrm{~V}$

$2 \mathrm{Cu}^{0}+\mathrm{O}_{2}+4 \mathrm{H}^{+} \rightarrow 2 \mathrm{Cu}^{2+}+2 \mathrm{H}_{2} \mathrm{O}$

$\Delta E^{0}=1.23-0.34=0.89 \mathrm{~V}$

$\mathrm{Cu}^{0}+2 \mathrm{Fe}^{3+} \rightarrow \mathrm{Cu}^{2+}+2 \mathrm{Fe}^{2+}$

$\Delta E^{0}=0.77-0.34=0.43 \mathrm{~V}$

$4 \mathrm{Fe}^{2+}+\mathrm{O}_{2}+4 \mathrm{H}^{+} \stackrel{\text { A.f. }}{\rightarrow} 4 \mathrm{Fe}^{3+}+2 \mathrm{H}_{2} \mathrm{O}$

$\Delta E^{0}=1.23-0.77=0.46 \mathrm{~V}$

The reactions that have the higher standard potential difference $\Delta E^{0}$ are the oxidation of $\mathrm{Al}^{0}$ by $\mathrm{Fe}^{3+}$ (Eq. (1), $\Delta E^{0}=2.43 \mathrm{~V}$ ) and the cementation of $\mathrm{Cu}^{2+}$ on $\mathrm{Al}^{0}$ (Eq. (2), $\Delta E^{0}=2.00 \mathrm{~V}$ ). Considering only the $\Delta E^{0}$, these two reactions should be the first reactions that occur in the studied system. The aluminium is thus in competition with the copper not only because it consumes $\mathrm{Fe}^{3+}$ but also because it reacts with the already dissolved copper. As it appears in Fig. 1, the aluminium is totally dissolved after $5 \mathrm{~h}$ while only $10 \%$ of the copper was dissolved. Since the cementation leads to a consumption of dissolved copper, this latter can only accumulate into the solution after the complete dissolution of aluminium. The cement is observed to form at the surface of aluminium and is removed through the agitation; it constitutes fine copper particles observable during the experiments. The cement was dissolved after the

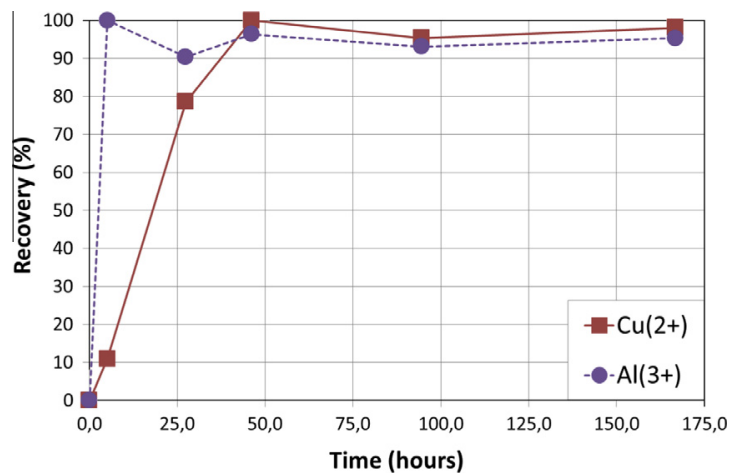

Fig. 1. Competition between the copper leaching and the aluminium leaching. The aluminium is leached before the copper (test $13-1 \mathrm{~g} / \mathrm{L} \mathrm{Fe}^{3+}$ ). dissolution of aluminium. This phenomenon was also observed in further experimental studies we performed on electronic waste recycling, for instance the leaching of printed circuit boards. Typically in electronic waste, copper can be in competition with aluminium, zinc and iron, depending on the waste composition. In this study, the copper is only in competition with the aluminium that will be dissolved first.

The oxidation of copper can be made by two different mechanisms: the oxidation by oxygen (Eq. (3)) and the oxidation by $\mathrm{Fe}^{3+}$ (Eq. (4)). Thermodynamically speaking, Eq. (3) is more plausible than Eq. (4): it presents a higher difference of standard potential $\Delta E^{0}$. However, it seems that it is not the most important mechanism, maybe due to oxygen transfer limitations from the gas phase into the liquid phase. In fact, the experimentation shows that the oxidation by $\mathrm{Fe}^{3+}$ is the most important mechanism. First, the copper leaching kinetics is very slow when the experimentation is made without addition of ferric iron. As described in Section 3.4, the copper leaching rate strongly increases with the $\mathrm{Fe}^{3+}$ concentration. The test 2 carried out without $\mathrm{Fe}^{3+}$ is associated with a long delay on the copper dissolution $(23 \mathrm{~h})$ and the lowest copper leaching rate $(19 \mathrm{mg} / \mathrm{L} \mathrm{h})$. However, when the $\mathrm{Fe}^{3+}$ concentration is close to zero, the copper dissolution is still feasible thanks to Eq. (3). Thus, ferric iron is not essential but it leads to significant acceleration of copper dissolution. At least two chemical mechanisms take place during the copper dissolution: the main mechanism is the oxidation by $\mathrm{Fe}^{3+}$ but the oxidation by $\mathrm{O}_{2}$ can also occur.

In addition of the chemical mechanisms linked with the metals dissolution, the oxidation of $\mathrm{Fe}^{2+}$ to form $\mathrm{Fe}^{3+}$ also takes place (Eq. (5)). This reaction can exist in a chemical system but it is catalysed in presence of iron-oxidant bacteria as A. ferrooxidans conditions. The present paper studies the improvement that may be achieved by using the biological leaching in addition to the chemical leaching.

\subsection{Kinetic modelling of the copper recovery rate}

To facilitate the comparison between the experiments, a modelling rate was used to model the copper recovery rate assuming that Eq. (4) is the main mechanism leading to the dissolution of copper. The rate law can be written as:

$\frac{d\left[\mathrm{Cu}^{2+}\right]}{d t}=-\frac{d\left[\mathrm{Fe}^{3+}\right]}{2 \cdot d t}=k \cdot\left[\mathrm{Cu}^{0}\right]^{a} \cdot\left[\mathrm{Fe}^{3+}\right]^{b}$

where the concentrations are given in mol/L, $k$ is the kinetic constant of the rate equation, $a$ and $b$ are the kinetic orders relative 
to $\mathrm{Cu}^{0}$ and $\mathrm{Fe}^{3+}$ respectively. In the present work we assume that the $\mathrm{Cu}^{0}$ is in large excess and remains constant at the beginning of the experiments, so the influence of $\mathrm{Cu}^{0}$ may be neglected in a first approach. Regarding the influence of $\mathrm{Fe}^{3+}$, two different models are proposed, depending on the initial $\mathrm{Fe}^{3+}$ concentration in the experiments.

The first model considers that the kinetics of copper leaching does not depend on the $\mathrm{Fe}^{3+}$ concentration. This is only valid at large ferric iron concentrations. In such cases, $\mathrm{Fe}^{3+}$ is in large excess and its concentration may be considered as a constant (it is thus included in the kinetic constant $k$ which becomes $\left.k^{\prime}=k \cdot\left[\mathrm{Fe}^{3+}\right]^{b}\right)$. As a result, the differential equation may be solved for the zeroorder model, leading to Eq. (7) (the concentration of $\mathrm{Cu}^{2+}$ at $t=0$ is 0 ):

$$
\left[\mathrm{Cu}^{2+}\right]=k^{\prime} \cdot t
$$

The second model assumes that $b=1$, so the kinetics of copper leaching linearly depends on the $\mathrm{Fe}^{3+}$ concentration. This value for $\mathrm{b}$ appeared to best describe the evolution of the $\mathrm{Cu}^{2+}$ concentration in solutions at low $\mathrm{Fe}^{3+}$ concentrations. In such cases, ferric iron is the limiting reactant, so it has to be considered in the kinetic rate expression. Similarly to the zero-order model, the differential equation may be solved for the first-order model, leading to Eq. (8) (equation is solved for $\mathrm{Fe}^{3+}$ assuming an initial concentration of $\mathrm{Fe}^{3+}$ equal to $\left.\left[\mathrm{Fe}^{3+}\right]_{0}\right)$ :

$\left[\mathrm{Fe}^{3+}\right]=\left[\mathrm{Fe}^{3+}\right]_{0} \cdot e^{-2 k t}$

If we assume that Eq. (4) represents the main mechanism taking place in the solution, the concentration of $\mathrm{Cu}^{2+}$ may be expressed in function of the $\mathrm{Fe}^{3+}$ concentration as following:

$\left[\mathrm{Cu}^{2+}\right]=\frac{\left[\mathrm{Fe}^{3+}\right]_{0}-\left[\mathrm{Fe}^{3+}\right]}{2}=\frac{1}{2} \cdot\left[\mathrm{Fe}^{3+}\right]_{0} \cdot\left(1-e^{-2 k t}\right)$

Considering that the copper recovery (in \%) is defined as $R=m_{\text {recovered } \mathrm{Cu}} / m_{\text {total } \mathrm{Cu}}$, then the recovery may be represented in function of the time. Fig. 2 compares the experimental measurements with the model-predicted copper recovery rate. The use of two models was necessary to minimise the gap between theoretical predictions and experimental result. The relevance of using two different modelling approaches (zero-order and first-order model) depending on the $\mathrm{Fe}^{3+}$ concentration clearly appears. Indeed, when the $\mathrm{Fe}^{3+}$ concentration is high, there is an excess of iron and the leaching rate does not depend on the concentration of iron anymore. However, when there is less $\mathrm{Fe}^{3+}$ in solution, then the first order assumption is necessary to properly describe the limiting effect of the $\mathrm{Fe}^{3+}$ concentration.

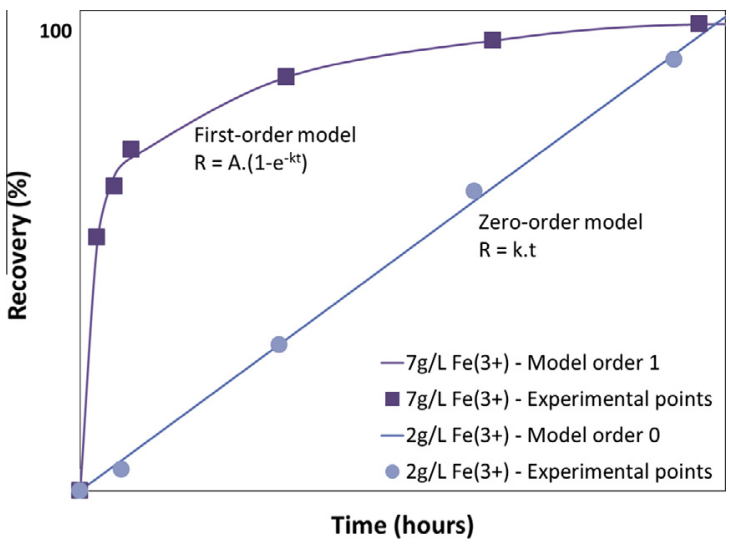

Fig. 2. Comparison between the two recovery models (first-order and zero-order) and the experimental results for the tests with an initial $\mathrm{Fe}^{3+}$ concentration of $7 \mathrm{~g} / \mathrm{L}$ and $2 \mathrm{~g} / \mathrm{L}$.

\subsection{Experimental results}

Table 2 presents the main experimental results that were obtained for the 14 tests described in Table 1. Tests were compared to each other by evaluating three different parameters: the time needed to obtain a copper recovery of $90 \%$, the maximal copper leaching rate and the acid consumption. The maximal copper leaching rate is the initial rate for all tests except the test 2 that presents a rate close to zero during the first day of the experiment. For this test, the maximal copper leaching rate is calculated when the copper dissolution begins. It was calculated by linear regression on the three first points for tests with $6-7 \mathrm{~g} / \mathrm{L} \mathrm{Fe}^{3+}$ (first-order model) whilst it corresponds to the slope of the recovery rate for tests with $0.5-2 \mathrm{~g} / \mathrm{L} \mathrm{Fe}^{3+}$ (zero-order model).

Besides the leaching time and the leaching rate, the model order was reported for each experiment, in agreement with the previous discussion about kinetic models. The measured acid consumption is expressed in mole of sulphuric acid per mole of dissolved copper. The stoichiometric acid consumption is the acid consumption predicted by the redox reactions of copper dissolution.

\subsection{Effect of the initial ferric iron concentration on copper leaching}

The ferric iron concentration has shown a noticeable effect on copper leaching kinetics. For the pure chemical leaching tests at $35^{\circ} \mathrm{C}$, the increase of initial ferric iron concentration from $0 \mathrm{~g} / \mathrm{L}$ to 2 and next $6 \mathrm{~g} / \mathrm{L}$ led to a higher copper leaching rate $(19 \mathrm{mg} /$ $\mathrm{L} \mathrm{h}$ to 65 and next $750 \mathrm{mg} / \mathrm{L}$ h respectively) and a lower leaching time: with $0 \mathrm{~g} / \mathrm{L} \mathrm{Fe}^{3+}$, copper extraction reached about $84 \%$ after 7 days, whilst similar copper extraction degree was reached after only 3 days for the test with $2 \mathrm{~g} / \mathrm{L} \mathrm{Fe}^{3+}$ and one day for the test with initially $6 \mathrm{~g} / \mathrm{L} \mathrm{Fe}^{3+}$ (Fig. 3).

Similar trend about the effect of the initial ferric iron concentration on copper dissolution rate could be observed for the biological leaching performed at $35^{\circ} \mathrm{C}$ (Fig. 5). Raising the initial concentration of ferric iron from 0 to 1,2 and $7 \mathrm{~g} / \mathrm{L}$ has brought concomitant increase in leaching velocities $(19,62,102$ and $713 \mathrm{mg} / \mathrm{L} \mathrm{h}$ respectively). As far as leaching duration is concerned, when $\mathrm{Fe}^{3+}$ was absent at the beginning, a leaching time of 7 days was needed to reach a copper extraction of $80 \%$, whilst when iron was supplied at 1 and $7 \mathrm{~g} / \mathrm{L}, 3$ days and 1 day were enough. These results confirm that $\mathrm{Fe}^{3+}$ plays an essential role in the kinetics of copper leaching in both biological and chemical systems. The presence of $\mathrm{Fe}^{3+}$ may enhance the oxidation of copper and thus improve its dissolution into the solution.

Table 2

Experimental results for the fourteen leaching experiments.

\begin{tabular}{rrllll}
\hline Tests & $\begin{array}{l}\text { Leaching } \\
\text { time }^{\mathrm{a}}(\mathrm{h})\end{array}$ & $\begin{array}{l}\text { Initial } \\
\text { leaching } \\
\text { rate }(\mathrm{mg} / \\
\mathrm{L} \mathrm{h})\end{array}$ & $\begin{array}{l}\text { Model } \\
\text { order } \\
(-)\end{array}$ & $\begin{array}{l}\mathrm{H}_{2} \mathrm{SO}_{4}{ }^{\mathrm{a}} \\
\text { consumption } \\
(\mathrm{mol} / \mathrm{mol} \\
\left.\mathrm{Cu}^{2+}\right)\end{array}$ & $\begin{array}{l}\text { Stoic. } \mathrm{H}_{2} \mathrm{SO}_{4}{ }^{\mathrm{a}} \\
\text { consumption } \\
\left(\mathrm{mol} / \mathrm{mol} \mathrm{Cu}^{2+}\right)\end{array}$ \\
\hline 1 & 77 & 450 & 1 & 1.81 & 0.21 \\
2 & $>167$ & 19 & 0 & 7.37 & 2.00 \\
3 & 112 & 63 & 0 & 1.54 & 1.83 \\
4 & 69 & 65 & 0 & 1.49 & 1.50 \\
5 & 36 & 750 & 1 & 1.67 & 0.36 \\
6 & 19 & 936 & 1 & 2.76 & 0.35 \\
7 & 119 & 30 & 0 & 2.87 & 1.77 \\
8 & 94 & 65 & 0 & - & 1.88 \\
9 & 67 & 62 & 0 & 2.80 & 1.70 \\
10 & 50 & 102 & 0 & 1.21 & 1.51 \\
11 & 23 & 713 & 1 & 0.79 & 0.19 \\
12 & 57 & 129 & 0 & 5.27 & 1.69 \\
13 & 32 & 151 & 0 & 1.25 & 1.83 \\
14 & 32 & 149 & 0 & 1.18 & 0.21 \\
\hline
\end{tabular}

a Calculated to reach a copper extraction of $90 \%$. 


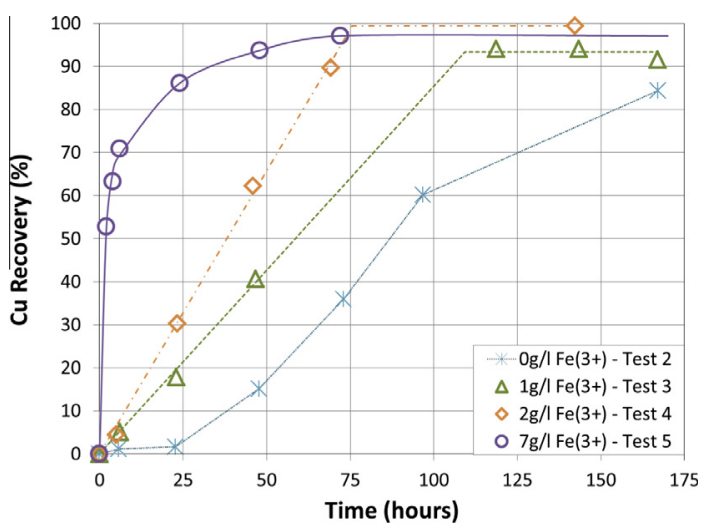

Fig. 3. Influence of initial $\mathrm{Fe}^{3+}$ concentrations on copper recovery during abiotic leaching. A higher initial $\mathrm{Fe}^{3+}$ concentration increase enables faster copper leaching kinetics.

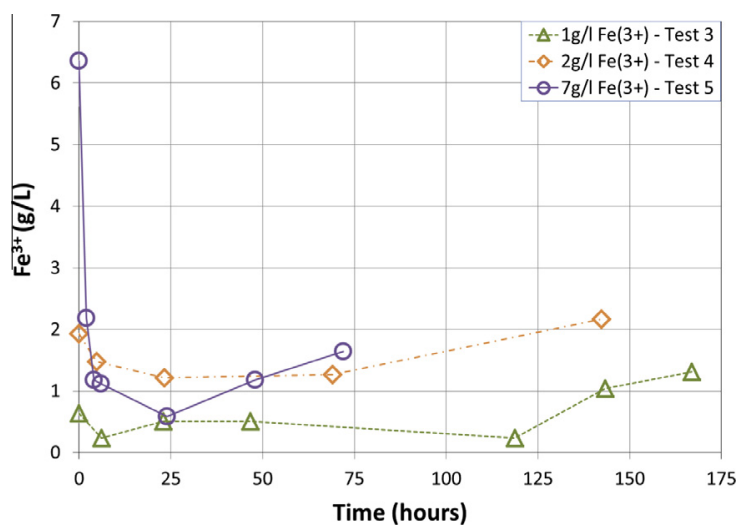

Fig. 4. Evolution of the $\mathrm{Fe}^{3+}$ concentration (g/L) for the abiotic tests 3,4 and 5 . The $\mathrm{Fe}^{3+}$ concentration rapidly decreases at the beginning of the experiment.

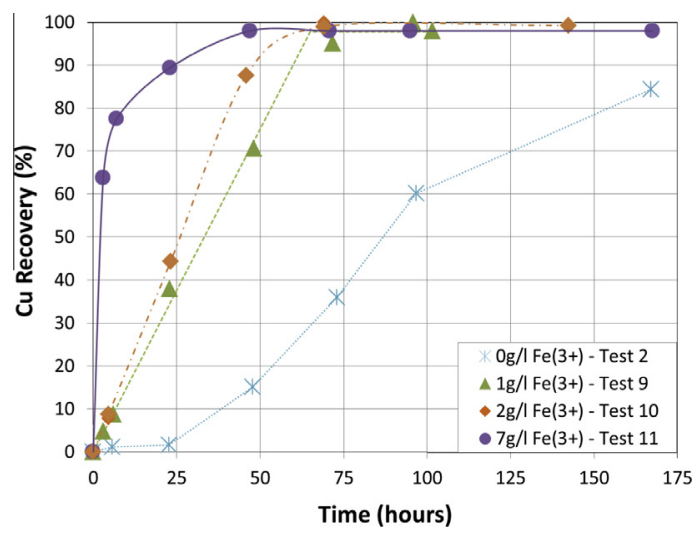

Fig. 5. Influence of initial $\mathrm{Fe}^{3+}$ concentration on copper recovery during biotic leaching. A higher initial $\mathrm{Fe}^{3+}$ concentration increase enables faster copper leaching kinetics.

For all the tests, the $\mathrm{Fe}^{3+}$ concentration strongly decreases at the beginning of the experiment, reaches the equilibrium concentration, and increases at the end of experiment when $\mathrm{Fe}^{3+}$ is no more consumed by $\mathrm{Cu}^{0}$ and can accumulate in the solution. The increase of the $\mathrm{Fe}^{3+}$ concentration at the end of experiment appears for both abiotic (Fig. 4) and biotic tests (Fig. 6) through the chemical oxidation of ferrous iron by oxygen.

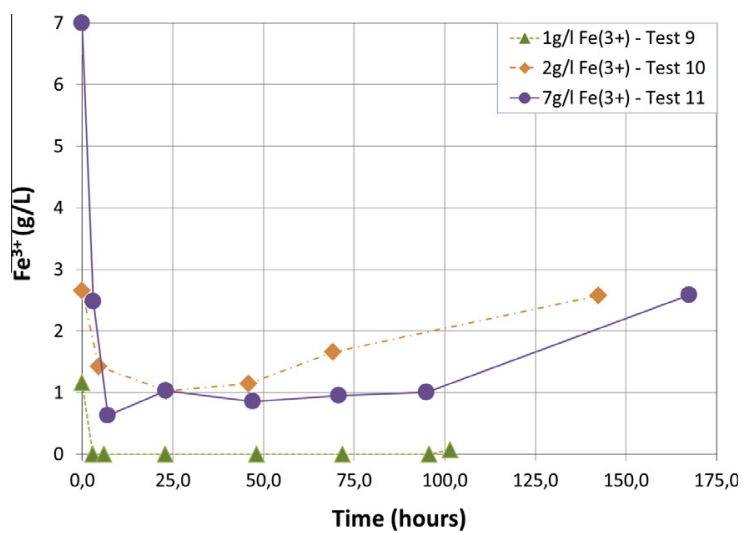

Fig. 6. Evolution of the $\mathrm{Fe}^{3+}$ concentration $(\mathrm{g} / \mathrm{L})$ for the abiotic tests 9,10 , and 11 .

\subsection{Effect of bacterial presence on copper leaching}

Bacterial action catalyses the ferric iron regeneration (Eq. (5)), and thus should improve the copper leaching kinetics, especially when the initial ferric iron amount is below the stoichiometric quantity required to totally dissolve the copper, calculated for the studied material as $9 \mathrm{~g} / \mathrm{L} \mathrm{Fe}^{3+}$. The influence of bacteria on copper leaching was studied both at low and high concentrations.

In the case of low ferric iron concentrations (fixed between 0.5 and $2 \mathrm{~g} / \mathrm{L} \mathrm{Fe}^{3+}$ for tests $3,4,8,9,10,13$ and 14 ), the effect of bacteria on copper leaching is not as visible as expected. High copper extractions were reached for all these tests ( $>90 \%$ after $2-5$ days, Table 2), including the abiotic tests for which the ferric iron regeneration is not catalysed by the bacterial action. When all other parameters remain constant, Fig. 7 evidences that the leaching time to reach a copper recovery of $90 \%$ for the biotic test is lower than the one for the abiotic test for the tests 10 and 4 (50 and $69 \mathrm{~h}$ ), 8 and 3 ( 94 and $112 \mathrm{~h}$ ) but not for the tests 13 and 14 that present exactly the same copper kinetics ( $32 \mathrm{~h}$ for the two tests). In the same way, the initial copper leaching velocities are higher for the biotic tests than for the abiotic tests for tests 10 and 4 (102 mg/L h and $65 \mathrm{mg} / \mathrm{L} \mathrm{h}$ ) but are similar for tests 3 and 8 (63 and $65 \mathrm{mg} / \mathrm{L} \mathrm{h}$ ) and tests 13 and 14 (151 and $149 \mathrm{mg} / \mathrm{L} \mathrm{h}$ ) (Table 2). The effect of bacteria is limited for the test 8 and was even inexistent for the test 14 .

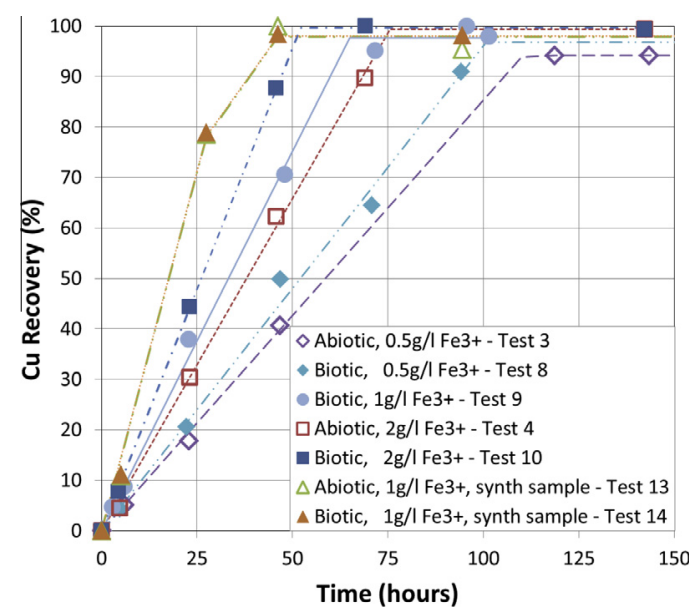

Fig. 7. Influence of bacteria presence on copper recovery (tests $3,4,8,9,10,13,14$; $35^{\circ} \mathrm{C}, 0-2 \mathrm{~g} / \mathrm{L} \mathrm{Fe}^{3+}$ ). Tests 13 and 14 were carried out with a synthetic sample (without plastics). The bacterial presence has a positive effect on copper recovery for the tests 8 and 10 , not for the 14 . 
This is particularly surprising for the test 14 , carried out with a simplified chemical system containing no plastics. Bacteria were only adapted to copper and aluminium, they should grow easier with pure metals than with the sample of electric cables that may contain contaminants. However, as described in Fig. 7, the biological test 14 does not outperform the chemical test 13: the kinetics of the copper leaching is the same for both tests.

Regarding the concentration of $\mathrm{Fe}^{3+}$ for the biotic test, it strongly decreases at the beginning of the experiment, reaches an equilibrium concentration, and increases at the end of experiment when $\mathrm{Fe}^{3+}$ is no more consumed by $\mathrm{Cu}^{0}$ and can accumulate in the solution (Fig. 8). The accumulation of $\mathrm{Fe}^{3+}$ is visible after the total dissolution of the copper, which means that the biological mechanism - that regenerates $\mathrm{Fe}^{3+}$ - is slower than the chemical one- that consumes $\mathrm{Fe}^{3+}$. It appears that the biological mechanism is too slow compared to the chemical one to detect a significant positive effect of the bacterial presence on copper leaching. The test 14 is the only test that presents a strong increase of the $\mathrm{Fe}^{3+}$ concentration at the end of the experiment. For other tests (tests $8,9,10)$, the $\mathrm{Fe}^{3+}$ concentration increases slightly at the end of the experiments but the shape of the curves are comparable to the ones of abiotic tests. This last result suggests that the bacteria activity is affected by the leaching environment.

The comparison between biotic and abiotic tests can also be made for the tests with a higher initial amount of ferric iron, corresponding to the stoichiometric amount required to totally dissolve the copper (tests 5 and 11). As for the tests with a limiting quantity of $\mathrm{Fe}^{3+}$, the presence of bacteria seems to have a low impact on copper leaching kinetics. Fig. 9 evidences that the time needed to dissolve $90 \%$ of the copper is lower for the biotic test than for the abiotic test ( 23 and $36 \mathrm{~h}$ respectively). However, as discussed previously, the positive effect of bacteria on copper recovery is small and could be assigned to an experimental error on the measurements. Besides, the $\mathrm{Fe}^{3+}$ concentration of the biotic test does not increase at the end of the experiment contrary to what was expected (Fig. 10).

The relatively low efficiency of the $\mathrm{Fe}^{3+}$ bio-oxidation (both at low and high $\mathrm{Fe}^{3+}$ concentrations) is surprising. One could think that bacteria could not adapt to the tests conditions and died during the experiments. Another explanation would be that the oxygen availability was not high enough for bacteria to be active. A last argument could be the non-adaptation of bacteria to plastics. However, none of these explanations is irrefutable. Firstly, bacteria were adapted to aluminium and copper concentrations and Fig. 11 indicates that a minimal concentration of $10^{4}$ bacteria $/ \mathrm{mL}$ is

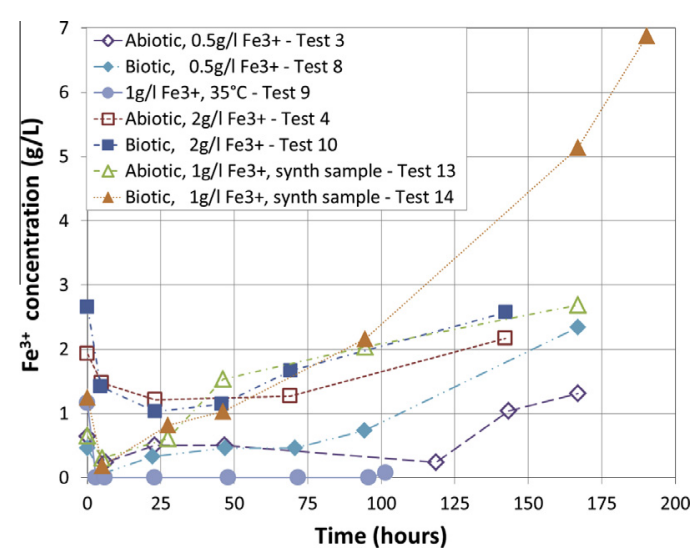

Fig. 8. Influence of bacteria presence on $\mathrm{Fe}^{3+}$ concentration (tests $3,4,5,9,11,12$; $35^{\circ} \mathrm{C}, 0-2 \mathrm{~g} / \mathrm{L} \mathrm{Fe}^{3+}$ ). Tests 13 and 14 were carried out with a synthetic sample (without plastics). The regeneration of $\mathrm{Fe}^{3+}$ by bacteria is too slow at the beginning of the biotic test to see a positive effect on copper leaching.

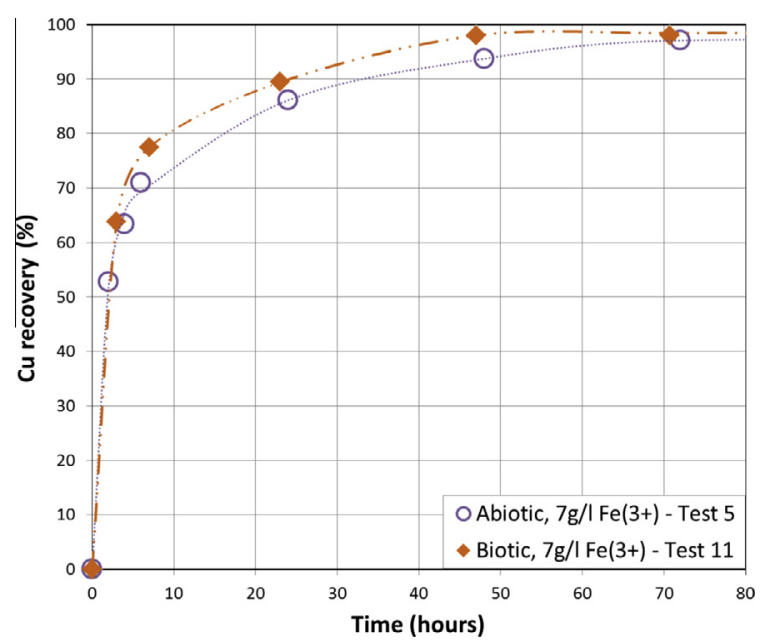

Fig. 9. Benefit of bacteria on copper leaching for the tests with a stoichiometric amount of $\mathrm{Fe}^{3+}$ : the copper leaching kinetics is slightly higher during the biotic test (test 13) than the abiotic test (test 6)

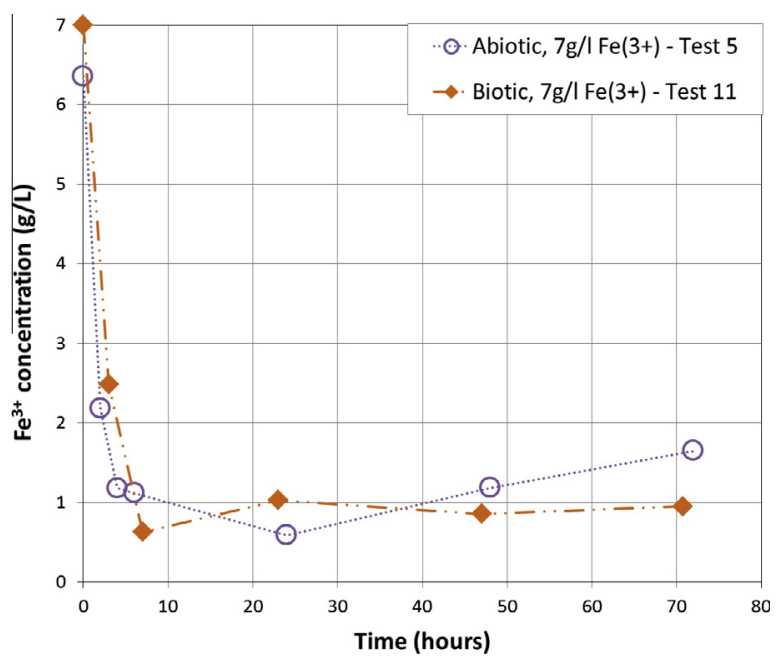

Fig. 10. Evolution of the $\mathrm{Fe}^{3+}$ concentration for the abiotic and biotic tests at $7 \mathrm{~g} / \mathrm{L}$ $\mathrm{Fe}^{3+}$.

maintained all along the experiments except for the test 12 that presents a huge diminution of bacteria by millilitre in solution. The low $\mathrm{Fe}^{2+}$ oxidation rate cannot thus be explained by a disappearance of microorganisms during the experiments. Secondly, the oxygen availability does neither explain the low $\mathrm{Fe}^{2+}$ oxidation. In fact, Liu et al. (1988) suggest that oxygen is limiting around $0.29-0.7 \mathrm{mg} / \mathrm{L}$ and that $A$. ferrooxidans does not grow at dissolved oxygen concentration lower than $0.2 \mathrm{mg} / \mathrm{L}$. Yet the minimal dissolved oxygen concentration measured during the biotic tests is higher than $1 \mathrm{mg} / \mathrm{L}$; the average of dissolved oxygen varies between $2.4 \mathrm{mg} / \mathrm{L}$ and $4.5 \mathrm{mg} / \mathrm{L}$ for the tests without air injection and is higher than $6 \mathrm{mg} / \mathrm{L}$ for the tests with air injection (Table 1).

Another explanation may be that the low bacterial action could be influenced by the presence of plastics. This is suggested by the observation of a delay of $18 \mathrm{~h}$ to reach a copper recovery of $90 \%$ between the biotic test with plastics (tests 9) and without (test 14). However, previous discussions have evidenced that the bacterial effect is too slow to be significant on copper leaching, even in the absence of plastics.

Finally, it appears that the $\mathrm{Fe}^{2+}$ oxidation rate in the fermenter in which bacteria were kept before their injection into the leaching reactor is also very low. The $\mathrm{Fe}^{2+}$ oxidation rate was calculated as 


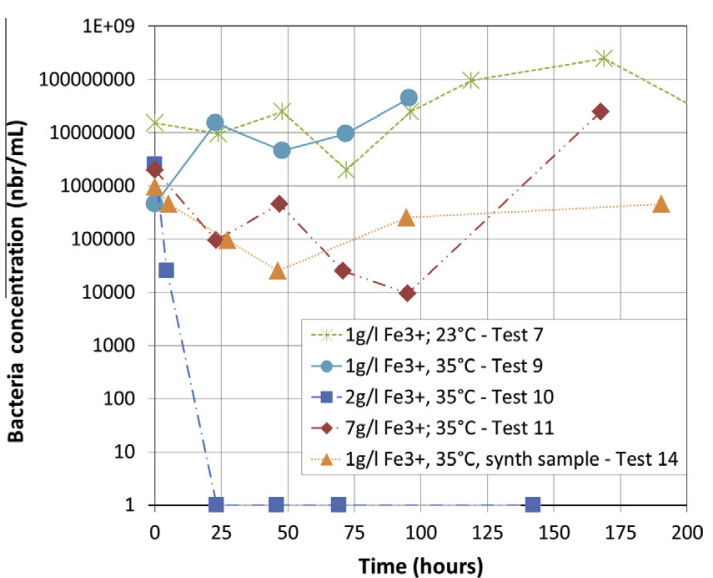

Fig. 11. Evolution of the bacteria concentration $(\mathrm{nbr} / \mathrm{mL})$ with time for the tests 8 , $10,11,12$ and 13.

$120 \mathrm{mg} / \mathrm{L} \mathrm{h} \mathrm{Fe}^{2+}\left(0.002 \mathrm{~mol} / \mathrm{L} \mathrm{h} \mathrm{Fe}^{2+}\right)$ at $\mathrm{pH}=1.9$ in the presence of $16.5 \mathrm{~g} / \mathrm{L} \mathrm{Cu}^{2+}, 3.5 \mathrm{~g} / \mathrm{L} \mathrm{Al}^{3+}$ and $10 \mathrm{~g} / \mathrm{L} \mathrm{Fe}^{2+}$. This iron oxidation rate is very low compared to the rate recorded in other studies. Kinnunen and Puhakka (2005) obtained an iron oxidation rate of $10 \mathrm{~g} / \mathrm{L} \mathrm{h} \mathrm{Fe}^{2+}$ at $\mathrm{pH}=0.9$ and in the presence of $21 \mathrm{~g} / \mathrm{L} \mathrm{Fe}^{2+}$ and $2 \mathrm{~g} / \mathrm{L} \mathrm{Cu}^{2+}$ with Leptospirillum ferriphilum. As a result, it appears that bacteria that were adapted to $\mathrm{Cu}^{2+}$ and $\mathrm{Al}^{3+}$ concentrations do not present good performance in terms of iron oxidation. The studied bacterial consortium showed its limitation. It is probably not the most appropriate choice to recover copper through bio-oxidation of $\mathrm{Fe}^{2+}$

\subsection{Effect of temperature on copper leaching}

Higher temperatures enable faster kinetic reactions in chemical systems. Therefore it is logical that for the case of chemical leaching only, the copper leaching kinetics has increased with temperature. As shown in Fig. 12, the leaching time needed the reach a copper recovery of $90 \%$ decreases from 77 to 36 and $19 \mathrm{~h}$ by increasing the temperature from $21^{\circ} \mathrm{C}$ to $35^{\circ} \mathrm{C}$ and $50{ }^{\circ} \mathrm{C}$ for the abiotic tests. The maximal copper leaching kinetics increases from 450 to 750 and $936 \mathrm{mg} / \mathrm{L}$. The initial $\mathrm{Fe}^{3+}$ concentration is not a limiting condition in these three tests carried out with $7 \mathrm{~g} / \mathrm{L} \mathrm{Fe}^{3+}$; the increase of the temperature has thus an impact less important than for the tests carried out with a low oxidant concentration (Tests $1,5,6$, Fig. 13). The increase of the temperature from $21^{\circ} \mathrm{C}$ to $50{ }^{\circ} \mathrm{C}$ enables an increase of the copper recovery of $13 \%$ after $24 \mathrm{~h}$.

As for the chemical tests, the kinetics of copper extraction of biotic tests increases with temperature (test 7, 9 and 12, Fig. 13.). This is surprising for biotic experiments, because the bacteria activity normally has an optimal temperature. Once again, this is due to the fact that the biological mechanism is too slow compared to the chemical one. As a consequence, the improvement observed at higher temperatures is due to the higher chemical activity independently of the presence of bacteria. Leaching durations have reached 119,67 and $57 \mathrm{~h}$ respectively at 21,35 and $50{ }^{\circ} \mathrm{C}$ (Table 2) and initial copper leaching kinetics were calculated as 30,62 and $129 \mathrm{mg} / \mathrm{L} \mathrm{h}$. At $50^{\circ} \mathrm{C}$, no biological mechanism takes place; no bacteria were detected at this temperature. Moreover, the comparison between Figs. 12 and 13 evidences that the temperature has a more pronounced influence on the copper leaching kinetics for low $\mathrm{Fe}^{3+}$ concentration.

Finally, for biotic and abiotic tests, temperature variations have shown an effect on the sulphuric acid consumption. This will be discussed in Section 3.7.

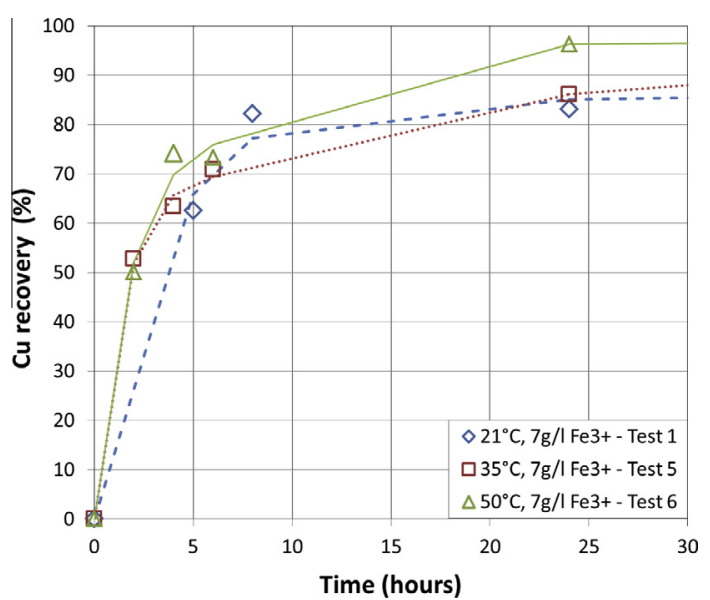

Fig. 12. Influence of temperature on copper recovery during abiotic leaching. The temperature increase enables faster copper leaching kinetics.

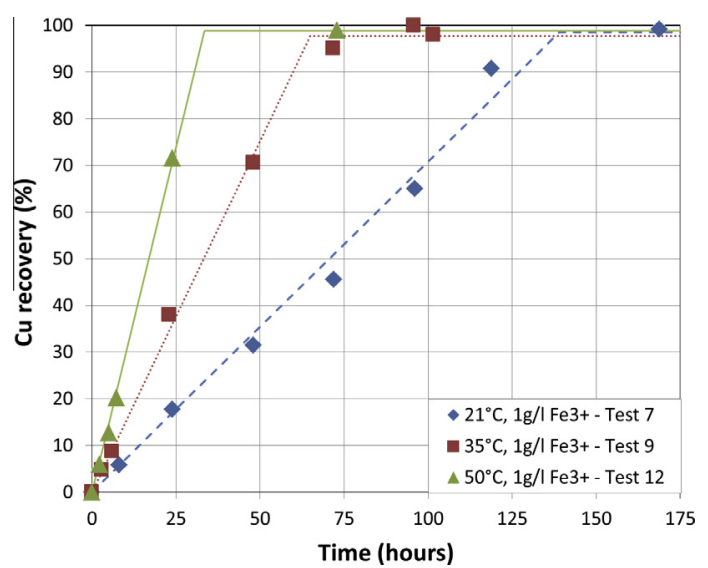

Fig. 13. Influence of temperature on copper recovery during biotic leaching. A temperature increase enables faster copper leaching kinetics.

\subsection{Sulphuric acid consumption}

The $\mathrm{pH}$ has to be controlled by addition of sulphuric acid during leaching experiments to avoid the precipitation of iron that takes place for $\mathrm{pH}$ higher than 2.5. The sulphuric acid consumption is an important parameter to take into account during the economic study of the process. The acid consumption can be divided in two parts: the useful part, that enables the copper dissolution (the stoichiometric acid consumption), and the non-useful part that corresponds to the acid consumed by others reactions. The non-useful consumed acid is for instance the acid used up by the aluminium oxidation and by the reaction between alkaline filler in plastics to form gypsum (Eq. (10)).

$\mathrm{CaCO}_{3}+\mathrm{H}_{2} \mathrm{SO}_{4} \rightarrow \mathrm{CaSO}_{4}+\mathrm{H}_{2} \mathrm{O}+\mathrm{CO}_{2}$

According to Eqs. (4) and (5), $2 \mathrm{~mol}$ of $\mathrm{Fe}^{3+}$ are needed to dissolve $1 \mathrm{~mol}$ of $\mathrm{Cu}^{0}$ and the regeneration of these $2 \mathrm{~mol}$ of $\mathrm{Fe}^{3+}$ requires $1 \mathrm{~mol}$ of $\mathrm{H}_{2} \mathrm{SO}_{4}$. So, the stoichiometric acid consumption can be calculated as:

$\mathrm{H}_{2} \mathrm{SO}_{4}\left(\mathrm{~mol} / \mathrm{mol} \mathrm{Cu}{ }^{2+}\right)=\frac{n_{\mathrm{Cu}^{0} \text { initial }}(\mathrm{mol})-\frac{1}{2} n_{\mathrm{Fe}^{3+} \text { initial }}(\mathrm{mol})}{n_{\mathrm{Cu}^{2+} \text { final }}(\mathrm{mol})}$

In Table 2, it appears that the actual acid consumption is higher than predicted by the stoichiometry for eight experiments (tests 1 , $2,5,6,7,9,12$ ). For these tests, the sulphuric acid is used for other chemical reactions than the copper dissolution. 
Normally, the biotic tests should be associated with a higher acid consumption, because the regeneration of $\mathrm{Fe}^{3+}$ consumes acid (Eq. (5)). This was besides observed in other studies (Lewis and et al., 2011). However, this is not the case for the tests carried out in the present work. The acid consumption of biotic tests $\left(1.21,0.79,1.18 \mathrm{H}_{2} \mathrm{SO}_{4} / \mathrm{mol} \mathrm{Cu}^{2+}\right.$ for tests $\left.10,11,14\right)$ is lower than the ones of abiotic tests made in the same conditions $(1.49,1.67$, $1.25 \mathrm{H}_{2} \mathrm{SO}_{4} / \mathrm{mol} \mathrm{Cu}^{2+}$ for tests $4,5,13$ ) (Table 2). The lower acid consumption in biotic test is currently not explained.

Finally, the acid consumption also depends on the temperature. The increase of temperature has led to higher acid demand to keep the $\mathrm{pH}$ constant and this observation was made for both the bio and the chemical leaching systems. Sulphuric acid consumption has increased from $1.81 \mathrm{~mol} \mathrm{H}_{2} \mathrm{SO}_{4} / \mathrm{mol} \mathrm{Cu}^{2+}$ at $21^{\circ} \mathrm{C}$ to $2.76 \mathrm{~mol}$ $\mathrm{H}_{2} \mathrm{SO}_{4} / \mathrm{mol} \mathrm{Cu}{ }^{2+}$ at $50{ }^{\circ} \mathrm{C}$ for abiotic tests $(1,5,6)$ and from $2.87 \mathrm{~mol} \mathrm{H}_{2} \mathrm{SO}_{4} / \mathrm{mol} \mathrm{Cu}^{2+}$ at $21^{\circ} \mathrm{C}$ to $5.27 \mathrm{~mol} \mathrm{H}_{2} \mathrm{SO}_{4} / \mathrm{mol} \mathrm{Cu}^{2+}$ at $50{ }^{\circ} \mathrm{C}$ for biotic tests $(7,11,12)$. The increase of the acid consumption with temperature may be attributed to a more pronounced plastics degradation phenomenon. In conclusion, large variations of the acid consumption was observed depending on the leaching conditions; an optimisation of these conditions may lead to a minimisation of the acid consumption.

\subsection{Chemical kinetics}

Considering the Arrhenius law, $k=A \cdot e^{\frac{-E_{a}}{R I}}$, Eq. (6) can be written as:

$\frac{d\left[\mathrm{Cu}^{2+}\right]}{d t}=A \cdot e^{\frac{-E_{a}}{R T}} \cdot\left[\mathrm{Cu}^{0}\right]^{a} \cdot\left[\mathrm{Fe}^{3+}\right]^{b}$

where $A$ is the pre-exponential constant, $E_{a}$ is the activation energy $\left(\mathrm{J} \mathrm{mol}^{-1}\right), R$ is the universal gas constant $\left(8.314 \mathrm{~J} \mathrm{~mol}^{-1} \mathrm{~K}^{-1}\right)$, and $T$ is the temperature $(\mathrm{K})$.

At the beginning of the experiments, we can consider that the $\mathrm{Cu}^{0}$ is in large excess and remains constant, so that the rate law may be simplified as:

$\frac{d\left[\mathrm{Cu}^{2+}\right]}{d t}=A \cdot e^{\frac{-E_{a}}{R T}} \cdot\left[\mathrm{Fe}^{3+}\right]^{b}$

The parameters $A, E_{a}$ and $b$ were optimised by the least squares method for biotic and abiotic test (Table 3 ). The activation energy of the copper dissolution through the reaction Eq. (12) was calculated to be $20.4 \mathrm{~kJ} / \mathrm{mol}$. This value has to be considered with caution because it was calculated with only three points of temperature. No value of the activation energy of the metallic copper dissolution in ferric sulphuric acid medium is available in the literature. Nevertheless, the calculated activation energy is close to other values of activation energy, as the activation energy of the dissolution of metallic copper in brønsted acidic ionic liquid $\left(E_{a}=25.4 \mathrm{~kJ} / \mathrm{mol}\right.$ ) (Huang and et al., 2014), the dissolution of metallic copper in nitric acid $\left(E_{a}=38.6 \mathrm{~kJ} / \mathrm{mol}\right.$ ) (Bas et al., 2014), the dissolution of copper sulphide in ferric sulphate media $\left(E_{a}=36.7 \mathrm{~kJ} / \mathrm{mol}\right.$ ) (Arslan and et al., 2004). The activation energy is a mean to determine which mechanism control the processes of the reactions: a chemical mechanism for value higher than $21 \mathrm{~kJ} / \mathrm{mol}$, a physical mechanism for value lower than $21 \mathrm{~kJ} / \mathrm{mol}$ (Rossi, 1990). The obtained activation energy is just at the boundary between the two mechanisms that makes difficult the interpretation.

The calculation of the rate law should not have a sense for biotic tests because the ferric iron is supposed to be regenerated by bacterial action, so that the rate expression may not be written in the same way. However, we obtained very close values of optimised parameters $\left(A, E_{a}\right.$ and $\left.b\right)$ for biotic and abiotic tests. This confirms
Table 3

Results of optimisation by the least squares method of $A, E_{a}$ and $b$ for abiotic and biotic tests.

\begin{tabular}{lll}
\hline & Abiotic & Biotic \\
\hline$A\left(\mathrm{~mol}^{0.5} \mathrm{l}^{-0.5} \mathrm{~h}^{-1}\right)$ & 751 & 876 \\
$E_{a}(\mathrm{~kJ} / \mathrm{mol})$ & 20.4 & 20.3 \\
$b(/)$ & 1.5 & 1.6 \\
\hline
\end{tabular}

once again that the biological mechanism has a low positive effect compared to chemical one on the copper leaching kinetics.

\section{Conclusions}

Leaching with ferric iron in sulphuric acid media either with or without bacteria is a promising way to dissolve zero-valent copper from low-grade waste like cable scraps. For all tests in the presence of $\mathrm{Fe}^{3+}$, copper extractions higher than $90 \%$ were achieved, both in bio and chemical leaching. Best copper leaching kinetics were reached for the biotic test at $35{ }^{\circ} \mathrm{C}$ with an initial concentration of $7.0 \mathrm{~g} / \mathrm{L} \mathrm{Fe}^{3+}$ and for the abiotic test at $50^{\circ} \mathrm{C}$ with an initial concentration of $6.4 \mathrm{~g} / \mathrm{L} \mathrm{Fe}^{3+}$. A copper recovery of $90 \%$ was achieved after one day for the two tests, but the lower-temperature test enables a lower sulphuric acid consumption $\left(0.93 \mathrm{~mol} \mathrm{H}_{2} \mathrm{SO}_{4} / \mathrm{mol}\right.$ $\mathrm{Cu}^{2+}$ against $2.76 \mathrm{~mol} \mathrm{H}_{2} \mathrm{SO}_{4} / \mathrm{mol} \mathrm{Cu}^{2+}$ for the test at $50{ }^{\circ} \mathrm{C}$ ).

Contrary to what was expected on the basis of the thermodynamics, the $\mathrm{Fe}^{3+}$ seems to be more active in the copper oxidation than $\mathrm{O}_{2}$. This latter oxidizes copper as well but at a slower kinetics. The $\mathrm{Fe}^{3+}$ concentration appears to be the more significant parameter that affects the copper leaching rate in the conditions investigated. A low $\mathrm{Fe}^{3+}$ concentration $(2 \mathrm{~g} / \mathrm{L})$ already enables interesting copper leaching kinetics (90\% Cu after 3 days); by increasing the concentration to $6 \mathrm{~g} / \mathrm{L}$, the leaching time can be further divided by three.

An increase of the temperature led to faster leaching kinetics, but also to an overconsumption of sulphuric acid to maintain the pH constant, probably due to a more pronounced degradation of the mineral material (filler) of the plastics present in the cable scraps. A temperature of $35^{\circ} \mathrm{C}$ seems to be the best compromise between efficient copper leaching kinetics and limited acid consumption.

Due to the effect of ferric iron regeneration by A. ferrooxidans, bacterial assisted leaching is associated with faster copper leaching but this increase of kinetics was relatively limited. This assumption is confirmed by the measurement of the reaction rate for both mechanisms. The chemical mechanism of copper dissolution is too fast compared to the bio-oxidation of $\mathrm{Fe}^{2+}$ to see a positive effect of the bacterial presence. The copper leaching rate varies between 0.001 and $0.011 \mathrm{~mol} / \mathrm{L} \mathrm{h}$, whilst the maximal $\mathrm{Fe}^{2+}$ oxidation rate was $0.002 \mathrm{~mol} / \mathrm{L} \mathrm{h}$. So the regeneration of $\mathrm{Fe}^{3+}$ by the bacterial action should only partially compensate the $\mathrm{Fe}^{3+}$ consumed by the copper. Note that the $\mathrm{Fe}^{2+}$ oxidation rate obtained in this work is very low compared to velocities obtained in other studies. The bacterial consortium is probably not the best choice to have a positive effect on copper leaching through the bio-oxidation of $\mathrm{Fe}^{2+}$. Further works include the study of other microorganisms cultures to increase the $\mathrm{Fe}^{2+}$ oxidation rate in presence of high copper concentration in the aim of optimising the biological mechanism.

Finally, the pre-exponential constant $A$, the activation energy $E_{a}$ and the kinetic order $\mathrm{b}$ of the kinetics law were calculated.

\section{Acknowledgement}

The authors would like to thank Dr Christopher Bryan for its advices in microbiology, Comet Traitements SA (Belgium) for its technical and financial assistance for the laboratory work and the 
Fonds De La Recherche Scientifique - FNRS (Belgium) for the financial support.

\section{References}

Arslan, F. et al., 2004. Studies on leaching of massive rich copper ore in acidic ferric sulfate solutions. Scand. J. Metall. 33 (1), 6-14.

Bas, A.D., Deveci, H., Yazici, E.Y., 2014. Treatment of manufacturing scrap TV boards by nitric acid leaching. Sep. Purif. Technol. 130, 151-159.

Brandl, H., Bosshard, R., Wegmann, M., 2001. Computer-munching microbes: metal leaching from electronic scrap by bacteria and fungi. Hydrometallurgy 59 (2-3), 319-326.

Gaydardzhiev, S., Bastin, D., Bareel, P.-F., 2010. Copper extraction from scrap cables by biotechnological means. In: XXV International Mineral Processing Congress (IMPC) - Proceedings. pp. 3751-3757.

Huang, J. et al., 2014. Leaching behavior of copper from waste printed circuit boards with brønsted acidic ionic liquid. Waste Manage. 34 (2), 483-488.

Ilyas, S. et al., 2007. Bioleaching of metals from electronic scrap by moderately thermophilic acidophilic bacteria. Hydrometallurgy 88 (1-4), 180-188.

Karavaiko, G.I., Rossi, G., Agate, A.D., Groudev, S.N., Avakyan, Z.A., 1988 Biotechnology of Metals - Manual. United Nations Environment Programme, Moscow.
Kinnunen, P.H.M., Puhakka, J.A., 2005. High-rate iron oxidation at below pH 1 and at elevated iron and copper concentrations by a Leptospirillum ferriphilum dominated biofilm. Process Biochem. 40 (11), 3536-3541.

Lewis, G. et al., 2011. Bio hydrometallurgical recovery of metals from fine shredder residues. Miner. Eng. 24 (11), 1166-1171.

Liang, G., Mo, Y., Zhou, Q., 2010. Novel strategies of bioleaching metals from printed circuit boards (PCBs) in mixed cultivation of two Acidophiles. Enzyme Microb. Technol. 47 (7), 322-326.

Liu, M.S., Branion, R.M.R., Duncan, D.W., 1988. The effects of ferrous iron, dissolved oxygen, and inert solids concentrations on the growth of Thiobacillus ferrooxidans. Can. J. Chem. Eng. 66 (3), 445-451.

Rossi, G., 1990. Biohydrometallurgy. McGraw-Hill Book Company GmbH, Hamburg, p. 609.

Wang, J. et al., 2009. Bioleaching of metals from printed wire boards by Acidithiobacillus ferrooxidans and Acidithiobacillus thiooxidans and their mixture. J. Hazard. Mater. 172 (2-3), 1100-1105.

Xiang, Y., Wu, P., Zhu, N., Zhang, T., Liu, W., Wu, J., Li, P., 2010. Bioleaching of copper from waste printed circuit boards by bacterial consortium enriched from acid mine drainage. J. Hazard. Mater. 184 (1-3), 812-818.

Yang, T., Xu, Z., Wen, J., Yang, L., 2009. Factors influencing bioleaching copper from waste printed circuit boards by Acidithiobacillus ferrooxidans. Hydrometallurgy 97 (1-2), 29-32. 